\title{
INCLUSION OF DRIED AGRO-INDUSTRIAL STRAWBERRY BY- PRODUCTS IN GROWING RABBIT DIETS
}

\author{
Amany H. Waly; M.M. Bassyony; Afaf H. Zedan and H.M.F. Galal \\ Animal Production Research Institute, Agricultural Research Center, Dokki, Giza, Egypt.
}

\section{SUMMARY}

\begin{abstract}
$\mathrm{T}$ his experiment was conducted to evaluate the effect of using dried strawberry by-product (ASB) in growing rabbit diets on growth performance, nutrients digestibility coefficients, some blood parameter and relative economic efficiency. Seventy two weaned male New Zealand White rabbits at 6 weeks received diets containing $0,25,50$ and $75 \%$ ASB as a replace of berseem hay. The growth trial lasted for 8 weeks. Results obtained could be summarized as follows: There were significant increases in body weight gain with increasing ASB levels in the diets. Whereas, feed consumption and feed conversion ratio were not significantly affected by ASB feeding. Ether extract digestibility coefficients were significantly decreased with increasing dietary level of ASB, while the digestibility coefficients of DM, OM, CP and CF were higher in treatments containing ASB, while the digestibility coefficients of $\mathrm{OM}, \mathrm{CP}$ and $\mathrm{CF}$ were significantly higher in treatments containing ASB. Dressing percentages of rabbits were significantly higher with 75\% ASB feeding compared with other treatments. Dietary ASB treatments had no significant effects on meat chemical analysis (moisture, DM and CP contents). But EE and ash contents were decreased with ASB feeding. Blood plasma concentrations of triglycerides, cholesterol, LDL, vLDL and total lipids were significantly decreased with increasing the level of ASB in rabbit diets. Feeding ASB had a significant positive effect on blood plasma antioxidant profile. Leveling up dietary ASB inclusion rate decreased MDA level and increased the TAC capacity in an incremental manner with increasing ASB of the diet. Using ASB as a feed ingredient improved the relative economic efficiency of diets. It could be concluded that ASB can be used in the growing rabbit diets with no adverse effects on performance and health status of the rabbit Besides, ASB could reduce the cost of the diet.
\end{abstract}

Keywords: Dried strawberry by-products, growing rabbit, performance, nutrients digestibility coefficients and blood parameters.

\section{INTRODUCTION}

Unconventional feedstuffs can offer a solution to extraordinary feed costs without compromising the nutritional value of animal comfort. The least cost diet formula is considered a target to rabbit nutritionists for achieving the best efficiency of utilization and economy in case of animal health and production. Berseem hay is the main plant source in rabbit diets. It is expensive in comparison to other nontraditional plant fiber sourcesthat have the privilege to enhance animal health and production.Hence, many feedstuffs, especially agro-industrial by-products which are usually of no feeding value to humans can alternatively be fed at a cheaper cost to rabbits (Obun et al., 2010). In Egypt, a considerable amount of food industry wastes is generated by the fruit-and-vegetable industries and handling estimates up to $30 \%$ of fruit and vegetable production (Industrial Union of Egypt, 2015). Studies concerning residual sources have been augmented considerably caused by a value adding recycling interest of the agro- and food industry, and also to increase information on the specific location of active compounds and their modification during processing (Alonso et al., 2002 and Amro et al., 2002).

Several studies reported that wastes and by-products of fruits may be an abundant source of antioxidant polyphenols (Peschel et al., 2006 and Wijngaard et al., 2009). Peschel et al., (2006) confirmed that agro industrial and agricultural wastes contain high amounts of phenolics and suggest the antioxidant recycling of the wastes of artichoke, apple and tomato; furthermore strawberry, asparagus or red beet. Vulić et al. (2011) reported that strawberry fresh pomace has a high content of polyphenolics $(488.12 \mathrm{mg} / 100 \mathrm{~g}$ fresh pomace), flavonoids $(296.11 \mathrm{mg} / 100 \mathrm{~g}$ fresh pomace) and anthocyanins (19.48 $\mathrm{mg} / 100 \mathrm{~g}$ fresh pomace).

Strawberry by-products (SBP) can be used as untraditional feed ingredients (Rus et al., 2011). Strawberry belongs to the subfamily Rosoideae of the Rosaceae family are known to have exceptionally rich secondary metabolite composition (Puupponen-Pimin et al., 2005; Koponen et al., 2007). 
Strawberry leaf includes tannins, flavonoids, a small amount of ascorbic acid and essential oils.Strawberry leaves could be used as appetizer, cholesterol and blood pressure lowering(Kümeli, 2006), and have an antioxidant activity (Ka“hko“nen et al., 2001 and Vulić et al., 2011). Goto et al. (2011) found that strawberry has a glycosides' flavonoid andpossesses anti-inflammatory, antioxidant activities.

Thehypotheses that polyphenolic as "-amylase inhibitor(resistant starch) from strawberry (Ellis et al., 2011) was also quite resistant to proteolytic digestion by trypsin (Yoshikawa et al., 1999) thatinduce delayed gastric emptying (Wicks et al., 2005) and has abilityto produce a large amount of butyrate as importantfood for cells lining colon (Donohoe et al., 2011) which make itpractically blocked by solidified digesta and theensuing bacterial fermentation stimulated the growthof this tissue by hyperplasia and hypertrophy (Pusztai et al., 1995) the resistant of strawberry by-product to rabbitalpha-amylase that produce a large amount of butyratewhich provides sufficient energy for colon cells (Champ et al., 2003) the limit doe of polyphenol from strawberry by-product has ability to inhibit alpha-amylase that may influence different steps in starch digestion in a synergistic manner (Mc-Dougall et al., 2005).

It can be maintained that strawberry by-products can be used as a good feed ingredient to replace clover hay in rabbit diets without any adverse effect on their performance and could be used economically in rabbit diet formulations (Omer et al., 2011).

The aim of the present investigation is to assess the effect of dried agro-industrialstrawberry byproduct (ASB) as a partial replacement on growth performance, digestibility coefficients, some blood parameter and economic efficiency of growing rabbits.

\section{MATERIALS AND METHODS}

The experimental work of this study was carried out at Borg-El Arab, Alexandria Governorate, Experimental Research Station, Animal Production Research Institute, Egypt.

Table (1). Feed ingredients and chemical composition of experimental diets (\%DM basis).

\begin{tabular}{|c|c|c|c|c|c|}
\hline \multirow{3}{*}{\multicolumn{2}{|c|}{ Feed Ingredients (\%) }} & \multirow[t]{3}{*}{ Control } & \multirow{3}{*}{$\frac{\mathrm{T}_{1}}{25 \% \text { ASB }}$} & \multirow{3}{*}{$\begin{array}{c}\mathrm{T}_{2} \\
50 \% \text { ASB }\end{array}$} & \multirow{3}{*}{$\begin{array}{c}\mathrm{T}_{3} \\
75 \% \\
\mathrm{ASB} \\
\end{array}$} \\
\hline & & & & & \\
\hline & & & & & \\
\hline $\begin{array}{l}\text { Dried Agro-industrial } \\
\text { (ASB) }\end{array}$ & By-products & 0 & 8.25 & 16.5 & 24.75 \\
\hline Berseem hay & & 33 & 24.75 & 16.5 & 8.25 \\
\hline Soybean meal (44\%CP) & & 17.15 & 17.65 & 18 & 18 \\
\hline Barley & & 20 & 19 & 18 & 17.65 \\
\hline Yellow corn & & 8 & 8 & 8 & 8 \\
\hline Wheat bran & & 15.5 & 16 & 16.65 & 17 \\
\hline Molasses & & 3 & 3 & 3 & 3 \\
\hline Limestone & & 0.95 & 0.95 & 0.95 & 0.95 \\
\hline Dicalcium - phosphate & & 1.6 & 1.6 & 1.6 & 1.6 \\
\hline Sodium chloride & & 0.3 & 0.3 & 0.3 & 0.3 \\
\hline DL-Methionine & & 0.2 & 0.2 & 0.2 & 0.2 \\
\hline Mineral-vitamin permix ${ }^{1}$ & & 0.3 & 0.3 & 0.3 & 0.3 \\
\hline Total & & 100 & 100 & 100 & 100 \\
\hline Total price feed/100 Kg (LE) & & 230 & 220 & 210 & 200 \\
\hline \multicolumn{6}{|l|}{ Chemical composition (\%DM basis) } \\
\hline Dry Matter\% & & 89.88 & 89.90 & 89.95 & 90.01 \\
\hline Organic Matter\% & & 90.99 & 90.89 & 90.83 & 90.81 \\
\hline Crude Protein $\%$ & & 16.72 & 16.28 & 16.17 & 16.06 \\
\hline Crude Fiber\% & & 13.56 & 13.21 & 13.15 & 13.09 \\
\hline Ether Extract\% & & 2.01 & 1.99 & 1.97 & 1.97 \\
\hline N-Free Extract $\%$ & & 58.70 & 59.41 & 59.54 & 59.69 \\
\hline Ash\% & & 9.01 & 9.11 & 9.17 & 9.19 \\
\hline Digestible energy $(\mathrm{Kcal} / \mathrm{kg} \mathrm{DM})^{2}$ & & 2510 & 2507 & 2500 & 2499 \\
\hline
\end{tabular}


${ }^{2}$ Digestible energy (DE) was calculated according to Fekete and Gippert (1986) using the following equation: DE $($ kcal/ $\mathrm{kg} \mathrm{DM})=4253-32.6(C F \%)-144.4$ (total ash).

Animals, housing, treatments and diets:

A total number of Seventy two of weaning male New Zealand White rabbits at 6 weeks of age and nearly equal average initial live body weight $(710.57 \mathrm{~g})$ were randomly assigned to four experimental treatment groups ( $\mathrm{n}=18$ in each) in a completely simple randomized design. Dried agro-industrial strawberry byproduct (ASB) was included in diets at levels of $0,8.25,16.5$ and 24.75 to replace $0,25,50$ and $75 \%$, respectively, of the berseem hay of the diets. The experimental period lasted for 8 weeks. ASB was obtained in a wet condition with moisture content from $65-70 \%$. The humidity of ASB was reduced by sun-drying to 9-10\%. Chemical analysis of ASB meal was carried out according (AOAC, 1996).

All rabbits were kept under the same management, hygienic and environmental conditions. Rabbits were individually housed in galvanized wire cages (Dimensions of $60 \times 40 \times 35 \mathrm{~cm}$ ) until marketing at 14 weeks of age under a 12:12 h light-dark cycle. All rabbits were fed pelletized feed ad libitum. Feed ingredients and chemical composition of experimental diets (\%DM basis) are shown in Table (1). The rabbits were reared in a well-ventilated building; fresh water was automatically available all the time by stainless steel nipples fixed in each cage.

All rabbit cages were equipped with feeders and nipples. Live Body weight was determined weekly throughout the experimental period, and weight gain was calculated. Feed consumption was determined precisely and calculated as grams per rabbit per day (during the all experimental period). Unused feed from each cage was collected daily, weighed and taken into consideration for the calculation of feed consumption, accordingly, feed conversion ratio was also calculated ( $\mathrm{g}$ feed / g gain).

\section{Digestibility and nitrogen balance trials:}

A total number of 16 male (4 males in each group) were used in carrying out the digestibility trial for determining nutrient digestibility co-efficient of the tested diets. Animals were housed individually in cages that allowed the separation of feces and urine. All rabbits were kept under the same management, hygienic and environmental conditions. The experimental diets were offered twice daily at 9 a.m. and 15 p.m. and fresh water was provided ad libitum. Survey of daily feed consumption was recorded. Any possible feed contamination was removed from the feces.

The trial lasted for 15 days, 8 days as a preliminary period followed by 7 days for measurements of actual feed consumption and feces output. Samples of daily feces of each rabbit were taken and oven dried at $70^{\circ} \mathrm{C}$ for $48 \mathrm{~h}$, then was ground and stored for proximate chemical analysis. Samples of feed and feces were analyzed for dry matter (DM), crude protein (CP), ether extract (EE), crude fiber (CF), and ash according to the classical (AOAC, 1996) methods. The nutritive value of the experimental diets as DCP and TDN value were calculated according to Cheeke (1987).

The urine of each animal was collected in a glass recipient, containing $10 \mathrm{ml}$ of a $1: 1 \mathrm{HCl}^{\mathrm{H}} \mathrm{H}_{2} \mathrm{O}$ solution, to avoid bacterial production and possible losses by volatilization. The chemical composition of feces, urine and feed was determined according to the methodologies described by Silva and Queiroz (2002). The values of nitrogen consumption (NC), nitrogen excreted in feces (NF) and nitrogen excreted in urine (NU) were obtained by multiplying nitrogen levels by the amounts of feed ingested and of feces and urine excreted, respectively; from those values, retained nitrogen was calculated as RN $=\mathrm{NC}-\mathrm{NF}-$ NU.

\section{Slaughtering and carcass traits:}

At the end of the experimental period (14 weeks old), five male rabbits from each group were randomly taken, fasted for $12 \mathrm{~h}$, individually weighed and immediately slaughtered. Slaughter procedure and carcass analysis were carried out as described by Blasco and Ouhayoun (1996). After complete bleeding, pelt, viscera's and tail were removed then the carcass and its components were weighed as edible parts. The non edible parts including lung, spleen, stomach, large intestine, small intestine and kidney fat were also weighed as percentage of pre-slaughter weight. Dressing percentage was calculated by dividing the hot dressed carcass weight by preslaughter weight and expressed as a percentage according to Steven et al. (1981).

\section{Blood Sampling and determination of biochemical parameters:}

Blood samples of five rabbits from each dietary treatment were collected during slaughtering to determine blood measurements. Blood plasma total protein, albumin, triglycerides, total cholesterol, LDL and HDL-cholesterol,vLDL, and total lipids were colormetrically determined using commercial kits (purchased from Bio-diagnostic, Egypt) according to the manufacturers' instructions. Plasma globulin concentration was calculated by difference was calculated. Blood plasma malondialdehyde (MDA) activity assayed using the method of Chiu et al., (1976). Total antioxidant capacity (TAC) was determined according to Diamond Bio diagnostic, Egypt. 


\section{Relative Economic efficiency:}

The relative economic efficiency of the experimental diets for the cost of feed required for producing one $\mathrm{kg}$ of body weight gain were calculated. The cost of the experimental diets was calculated according to the price of different ingredients prevailing in local market as well as the price of testing materials at the time of experimentation. Economic efficiency was calculated as a ratio between the return of weight gain and the cost of consumed feed.

\section{Statistical Analysis:}

The obtained data were statistically analyzed using SAS $^{\circledR}$ Software Statistical Analysis (SAS 1999). Differences among means were tested by Duncan's Multiple Range Test (Duncan, 1955).

\section{RESULTS AND DISCUSSION}

\section{Chemical composition of ASB and berseemhay:}

Chemical compositionof dried agro-industrial strawberry by-product (ASB) and berseem hayare shown in Table (2). The chemical analysis of DM and OM were higher in berseem hay compared to ASB. The chemical composition of NFE and ash in ASB was higher compared to berssem hay. On the other hand, berssem hay content of CF, CP and EE were higher than ASB. Na and K were higher in ASB were as Fe, Mn, $\mathrm{Zn}$ and $\mathrm{Ca}$ was higher in berssem hay. ASB contain higher amount of flavonoid (20.42).

\section{Growth Performance:}

Effects of experimental diets on growth performance from 6 to 14 weeks of age are presented in Table (3). Rabbits fed diets containing different levels of ASB had significantly higher body weight values compared to the control group at the end of the study.

Table (2). Chemical analysis of Dried Agro-industrial Strawberry by-product and Berseem hay.

\begin{tabular}{lcc}
\hline Item & Dried Strawberry By-product(ASB) & Berseem hay \\
\hline Chemical analysis, (\%) & & \\
Dry matter (DM) & 93.18 & 95.12 \\
Chemical analysis on DM basis & & \\
Organic matter (OM) & 80.68 & 89.59 \\
Crude protein (CP) & 7.38 & 10.64 \\
Crude fiber (CF) & 11.65 & 38.54 \\
Ether extract (EE) & 0.89 & 1.03 \\
Nitrogen-free extract (NFE) & 60.76 & 39.38 \\
Ash & 19.32 & 10.41 \\
Gross energy (Kcal/kg DM) ${ }^{1}$ & 3506 & 3932 \\
Digestible energy (Kcal/kg DM) ${ }^{2}$ & 1083.40 & 1493.39 \\
Non fibrous carbohydrates (NFC) & & 22.03 \\
Cell wall constituents & 40.12 & \\
Neutral detergent fiber (NDF) & & 55.89 \\
Acid detergent fiber (ADF) & 32.29 & 43.27 \\
Acid detergent lignin (ADL) & 24.19 & 37.19 \\
Hemicellulose & 15.78 & 12.62 \\
Cellulose & 8.1 & 6.08 \\
Fe (ppm) & 8.41 & 471.2 \\
Mn (ppm) & 242.88 & 31.94 \\
Zn (ppm) & 17.987 & 30.38 \\
Na (ppm) & 19.02 & 19211 \\
Ca (ppm) & 2777 & 8564 \\
K (ppm) & 7075 & 10890 \\
Flavonoid on dry matter, mg/ 100gm & 20114 & ND* \\
\hline${ }^{2}$ Digestible energy (DE) was calculated according to Fekete and Gippert using the following equation: $D E$ (kcal/ kg DM) \\
4253-32.6(CF \%)-144.4 (total ash). & & \\
& &
\end{tabular}


${ }^{3}$ Non fibrous carbohydrates (NFC), calculated according to Calsamiglia et al. using the following equation: NFC $=100-\{C P$ $+E E+A s h+N D F\}$.

Hemicellulose $=N D F-A D F$.

Cellulose $=A D F-A D L$.

The improvement in final body weight were 3.6, 3.1 and $4.3 \%$ for rabbits receiving 25,50 and $75 \%$ ASB, respectively compared to control rabbits. There were no significant differences in live body weight gain during each of the studied intervals except for the period 8-10 weeks of age where feeding 75\% ASB resulted in the highest weight gain compared to other treatments, while there were significant improve in total BWG in ASB containing diets compared with control group.

The reported improvements in final live body weight with the increase in dietary ASB could be partially attributed to the significant improvements in CP and CF digestibility coefficients (table 4). Also, the improvement in body weight and body weight gain may be due to antioxidant activity and phenolic content in ASB (Alvarez-Suarez et al., 2011). Strawberry contains sulfur volatiles (Du, 2011), which is the main component of the biochemical structure of the amino acids such as cysteine, methionine, taurine and glutathione (McGrath and Raines, 2011). All these bioactive compounds could result in further enhancement of growth performance of the rabbit.

Feed consumption was affected $(\mathrm{p}<0.05)$ by experimental treatments $(\mathrm{ASB})$ at $8-10$ weeks and $12-14$ week of age. Rabbits supplied with $50 \%$ ASB in their diet had a pronounced decrease $(\mathrm{p}<0.05)$ in feed consumption by $9.3 \%$ compared to the control diet at 8-10 week of age. On the other hand, the same treatment resulted in a significant increase in feed consumption during 12-14 weeks of age followed by those groups fed 25\% ASB in their diets, compared to 75\% ASB feeding or the control rabbits.

Feed conversion ratios were significantly improved by including different levels of ASB in the diets during 10-12 week of the study. The improvements in feed conversion ratio ranged between $8.2-8.3 \%$ of the groups fed 25, 50 and $75 \%$ ASB substituted for berseem hay. The best significant total FCR was for the treatment with $75 \%$ ASB feeding compared to the control group. These results may attribute to the effect of resistance starch in strawberry by-product which suitable to improve the caecum fiber digestion by eliminating the hazard microorganisms (Duan and Zhao, 2009).

Table (3). Means of growth performance of growing rabbits fed diets contain different levels of ASB substitution with berseem hay.

\begin{tabular}{|c|c|c|c|c|c|c|}
\hline \multirow[b]{2}{*}{ Items } & \multicolumn{4}{|c|}{ ASB } & \multirow[b]{2}{*}{ SEM } & \multirow[b]{2}{*}{ significance } \\
\hline & $\begin{array}{c}\text { Control } \\
\text { zero }\end{array}$ & $\begin{array}{c}\mathrm{T}_{1} \\
(25 \%)\end{array}$ & $\begin{array}{c}\mathrm{T}_{2} \\
(50 \%)\end{array}$ & $\begin{array}{c}\mathrm{T}_{3} \\
(75 \%)\end{array}$ & & \\
\hline \multicolumn{7}{|l|}{ Live Body weight, $\mathrm{g}$} \\
\hline $\begin{array}{l}\text { at } 6 \text { week } \\
\text { at } 8 \text { week }\end{array}$ & $\begin{array}{c}690.56 \\
111528\end{array}$ & $\begin{array}{c}716.72 \\
113722\end{array}$ & $\begin{array}{l}715.89 \\
112961\end{array}$ & $\begin{array}{l}719.11 \\
114167\end{array}$ & $\begin{array}{l}13.73 \\
2956\end{array}$ & NS \\
\hline at 10 week & 1551.44 & 1581.89 & 1562.94 & 1620.50 & 3153 & NS \\
\hline at 12 week & $1964.59^{b}$ & $2017.61^{\mathrm{ab}}$ & $2012.47^{\mathrm{ab}}$ & $2053.33^{\mathrm{a}}$ & 23.60 & * \\
\hline at 14 week & $2322.33^{b}$ & $2405.18^{\mathrm{a}}$ & $2393.18^{\mathrm{a}}$ & $2421.12^{\mathrm{a}}$ & 23.08 & * \\
\hline \multicolumn{7}{|l|}{ Body weight gain, g } \\
\hline $6-8$ week & 424.72 & 420.50 & 413.72 & 422.56 & 25.23 & NS \\
\hline 8-10 week & $436.17^{b}$ & $444.67^{\mathrm{ab}}$ & $428.24^{b}$ & $478.83^{\mathrm{a}}$ & 13.36 & $*$ \\
\hline 10-12 week & 402.47 & 437.18 & 449.35 & 432.83 & 17.27 & NS \\
\hline 12-14 week & 347.80 & 380.59 & 380.71 & 376.47 & 17.78 & NS \\
\hline Total BWG, g & $1628.73^{b}$ & $1686.59^{\mathrm{ab}}$ & $1678.12^{\mathrm{ab}}$ & $1705.88^{\mathrm{a}}$ & 0.88 & $*$ \\
\hline \multicolumn{7}{|l|}{ Feed Consumption, $\mathrm{g}$} \\
\hline 6-8 week & 512.77 & 476.12 & 477.77 & 455.52 & 14.54 & NS \\
\hline $8-10$ week & $825.46^{\mathrm{a}}$ & $829.38^{a}$ & $755.22^{b}$ & $809.14^{\mathrm{a}}$ & 10.30 & $*$ \\
\hline 10-12 week & 1209.48 & 1198.47 & 1245.16 & 1178.59 & 35.52 & NS \\
\hline 12-14 week & $1247.31^{\mathrm{b}}$ & $1338.48^{\mathrm{ab}}$ & $1375.38^{\mathrm{a}}$ & $1272.29^{b}$ & 33.14 & * \\
\hline Total FI, g & 3810.43 & 3841.48 & 3861.05 & 3754.51 & 1.46 & NS \\
\hline \multicolumn{7}{|c|}{ Feed conversion ratio, ( $\mathrm{g}$ feed / g gain) $\%$} \\
\hline $6-8$ week & 1.27 & 1.19 & 1.21 & 1.18 & 0.06 & NS \\
\hline $8-10$ week & $1.92^{\mathrm{a}}$ & $1.89^{\mathrm{a}}$ & $1.79^{\mathrm{ab}}$ & $1.70^{\mathrm{b}}$ & 0.05 & * \\
\hline 10-12 week & $3.01^{\mathrm{a}}$ & $2.79^{\mathrm{b}}$ & $2.78^{b}$ & $2.78^{b}$ & 0.07 & $*$ \\
\hline 12-14 week & 3.63 & 3.62 & 3.66 & 3.50 & 0.13 & NS \\
\hline FCR & $2.34^{\mathrm{a}}$ & $2.28^{\mathrm{ab}}$ & $2.31^{\mathrm{ab}}$ & $2.21^{\mathrm{b}}$ & 0.05 & $*$ \\
\hline Duration period, $56 \mathrm{c}$ & ays & & & & & \\
\hline
\end{tabular}

$* a, b, c$ and $d$ : Means in the same row having different superscripts differ significantly $(P<0.05)$.

NS not significance. 
Also, these significant results may be due to the antioxidant activity and phenolic content in strawberry by-products as well as with the capacity of promoting the action of antioxidant enzymes (Alvarez-Suarez et al., 2011), while the insignificant effect on feed consumption may be due to the unpleasant smell of butyric acid which configured as a result of resistant starch (Champet al., 2003). These results may be due to the sulfur volatiles in strawberry ( $\mathrm{Du}$ et al., 2011), which is a main component of the biochemical structure of the amino acids such as cysteine, methionine, taurine and glutathione (McGrath and Raines, 2011). In this respect, Omer et al. (2011) reported that rabbits received a basal diet with replacement strawberry by-products at the level $100 \%$ of clover hay increased the final body weight, total body weight gain and average daily gain by $10.25,13.78$ and $13.79 \%$, respectively.

\section{Nutrient digestibilitycoefficients and nutritive values of the experimental diets:}

Digestibility coefficients and nutritive values of the experimental diets are shown in Table (4). Dietary treatments had no significant effects on dry matter (DM) and nitrogen free extract (NFE) digestibility coefficients.

Table (4).Nutrient digestibility coefficients and nutritive values of growing rabbits fed diets containing different levels of ASB.

\begin{tabular}{|c|c|c|c|c|c|c|}
\hline \multirow[b]{2}{*}{ Item } & \multicolumn{4}{|c|}{ Treatments } & \multirow[b]{2}{*}{ SEM } & \multirow[b]{2}{*}{ Sign. } \\
\hline & $\begin{array}{c}\text { Control } \\
\text { zero }\end{array}$ & $\begin{array}{c}\mathrm{T}_{1} \\
25 \%\end{array}$ & $\begin{array}{c}\mathrm{T}_{2} \\
50 \%\end{array}$ & $\begin{array}{c}T_{3} \\
75 \%\end{array}$ & & \\
\hline $\mathrm{DM}$ & 67.70 & 67.87 & 65.94 & 68.25 & 1.62 & NS \\
\hline $\mathrm{OM}$ & $74.28^{b}$ & $74.99^{\mathrm{b}}$ & $77.85^{\mathrm{a}}$ & $74.56^{\mathrm{b}}$ & 1.71 & $*$ \\
\hline $\mathrm{CP}$ & $76.03^{b}$ & $76.69^{b}$ & $80.78^{\mathrm{a}}$ & $79.33^{\mathrm{a}}$ & 2.19 & $*$ \\
\hline $\mathrm{CF}$ & $42.69^{c}$ & $55.64^{\mathrm{b}}$ & $60.72^{\mathrm{a}}$ & $61.57^{\mathrm{a}}$ & 1.11 & $*$ \\
\hline $\mathrm{EE}$ & $65.42^{\mathrm{a}}$ & $59.69^{\mathrm{b}}$ & $55.45^{\mathrm{b}}$ & $52.99^{\mathrm{b}}$ & 2.32 & $*$ \\
\hline NFE & 81.57 & 81.31 & 80.09 & 79.28 & 1.34 & NS \\
\hline \multicolumn{7}{|l|}{ Nutritive value (\%DM) } \\
\hline DCP & $13.97^{b}$ & $14.11^{\mathrm{b}}$ & $15.20^{\mathrm{a}}$ & $14.30^{\mathrm{ab}}$ & 0.71 & $* *$ \\
\hline TDN & $53.11^{\mathrm{b}}$ & $55.10^{\mathrm{a}}$ & $56.00^{\mathrm{a}}$ & $53.90^{\mathrm{b}}$ & 1.79 & $*$ \\
\hline \multicolumn{7}{|l|}{ N-balance } \\
\hline N-intake (IN, g/day) & 3.38 & 3.37 & 3.26 & 3.15 & 0.19 & NS \\
\hline Faecal-N (FN, g/day) & $1.03^{\mathrm{a}}$ & $0.99^{\mathrm{ab}}$ & $0.97^{\mathrm{ab}}$ & $0.79^{\mathrm{b}}$ & 0.21 & $* *$ \\
\hline Urinary-N (UN, g/day) & $0.99^{\mathrm{a}}$ & $0.98^{\mathrm{a}}$ & $0.87^{\mathrm{ab}}$ & $0.77^{\mathrm{b}}$ & 0.11 & $*$ \\
\hline Digestible N (DN, g/d) & 2.35 & 2.38 & 2.29 & 2.36 & 1.13 & NS \\
\hline Retained N(RN, g/d) & $1.36^{\mathrm{b}}$ & $1.40^{\mathrm{b}}$ & $1.42^{\mathrm{b}}$ & $1.59^{\mathrm{a}}$ & 0.09 & $*$ \\
\hline $\mathrm{DN} / \mathrm{IN}(\%)$ & $69.53^{\mathrm{b}}$ & $70.62^{\mathrm{b}}$ & $70.25^{\mathrm{b}}$ & $74.92^{\mathrm{a}}$ & 1.70 & $*$ \\
\hline RN/IN (\%) & $40.24^{\mathrm{b}}$ & $41.54^{\mathrm{b}}$ & $62.01^{\mathrm{b}}$ & $50.48^{\mathrm{a}}$ & 1.16 & $*$ \\
\hline RN/DN (\%) & $57.87^{\mathrm{b}}$ & $58.82^{\mathrm{b}}$ & $55.61^{\mathrm{b}}$ & $67.37^{\mathrm{a}}$ & 0.79 & $*$ \\
\hline
\end{tabular}

$D N=I N-\square F N . R N=I N \square-F N \square-U N$.

$D N / I N(\%)=$ the efficiency of intake $N$ converted into digestible $N$.

$R N / I N(\%)=$ the efficiency of intake $N$ converted into retained $N$.

$R N / D N(\%)=$ the efficiency of digestible $N$ converted into digestible $N$.

NS not-significance.

Rabbits received diets 50\% ASB recorded significantly the highest digestibility coefficients of organic matter (OM) and nutritive values as total digestible nutrient (TDN) or digestible crude protein (DCP) when compared with the rest treatments or control diets. The highest digestibility coefficients of crude protein $(\mathrm{CP})$ and crude fiber $(\mathrm{CF})$ were recorded for the rabbits that fed on diets containing 50 and $75 \%$ ASB when compared with a control group or with that containing $25 \%$ ASB in their diets. The digestibility coefficients of ether extracts (EE) significantly decreased with increasing the dietary level of ASB when compared with the control group.

The effects of the ASB on $\mathrm{N}$ balance are shown in Table 4. The fecal N (FN) and urinary-N (UN) were significantly decreased, while retaining $\mathrm{N}(\mathrm{RN})$, the efficiency of consumption $\mathrm{N}$ converted into digestible $\mathrm{N}$ (DN/IN) and the efficiency of consumption $\mathrm{N}$ converted into retained $\mathrm{N}$ (RN/IN) significantly increased with the $75 \%$ ASB compare to other treatments. In addition, no significant effect was observed on $\mathrm{N}$ consumption (IN) and the efficiency of digestion $\mathrm{N}$ (DN) between treatments. Increased digestibility and $\mathrm{N}$-utilization may be due to positive impacts of ASB on absorption and utilization of nutrients. 
The improvement in digestion coefficient and nitrogen balance when using ASB as a feed may be due to that polyphenolic from strawberry may: 1-resiste proteolytic digestion by trypsin (Yoshikawa et al., 1999). 2- Delayed gastric emptying (Wicks et al., 2005). 3- Has abilityto produce a large amount of butyrate as an importantfood for cells lining the colon (Donohoe et al., 2011). On the other hand, the resistant of strawberry by-product to rabbitalpha-amylase that produce a large amount of butyrate, which provides sufficient energy for colon cells (Champ et al., 2003) the limit doe of polyphenol from strawberry by-product has ability to inhibit alpha-amylase that may influence different steps in starch digestion in a synergistic manner (Mc-Dougall et al., 2005).

\section{Carcass traits and chemical composition:}

Results of carcass traits studied are shown in Table 5. Dressing, edible giblets and total edible parts percentage of rabbits fed $75 \%$ ASB diet was significantly higher than the other treatments. These results may be due to the tiliroside contained in strawberry which inhibits obesity-induced hepatic and muscular triglyceride accumulation, (Goto et al., 2011). In this connection, Omer et al., (2011) claimed that rabbits received a basal diet with replacement dried agro-industrial strawberry by-products at the level $100 \%$ of berseem hay recorded the highest value of liver weight and total giblets weight.

The effect of dietary treatments on chemical analysis of the meat carcass is shown in Table 5. ASB treatments had no significant effects on chemical analysis of moisture, DM, and CP contents of the meat. However, ether extract and ash in the meat of the rabbits fed on different levels 25, 50 and $75 \%$ ASB were significantly decreased when compared with the control group.

Table (5).Carcass traits and chemical analysis of the meat carcass of growing rabbits fed diets containing different levels of ASB.

\begin{tabular}{|c|c|c|c|c|c|c|}
\hline \multirow[b]{2}{*}{ Item } & \multicolumn{4}{|c|}{ Treatments } & \multirow[b]{2}{*}{ SEM } & \multirow[b]{2}{*}{ Sign. } \\
\hline & $\begin{array}{c}\text { Control } \\
\text { zero }\end{array}$ & $\begin{array}{c}\mathrm{T}_{1} \\
25 \%\end{array}$ & $\begin{array}{c}\mathrm{T}_{2} \\
50 \%\end{array}$ & $\begin{array}{c}\mathrm{T}_{3} \\
75 \%\end{array}$ & & \\
\hline Pre-slaughter weight (g) & 2232.4 & 2225.6 & 2236.4 & 2214.5 & 62.5 & NS \\
\hline Dressing \% & $57.00^{\mathrm{b}}$ & $58.70^{\mathrm{b}}$ & $61.24^{\mathrm{ab}}$ & $63.70^{\mathrm{a}}$ & 1.7 & $*$ \\
\hline Edible giblets $\%$ & $3.20^{\mathrm{b}}$ & $3.15^{\mathrm{b}}$ & $3.32^{\mathrm{ab}}$ & $3.42^{\mathrm{a}}$ & 0.01 & $*$ \\
\hline Total edible parts $\%$ & $60.20^{\mathrm{b}}$ & $61.85^{\mathrm{b}}$ & $64.56^{\mathrm{ab}}$ & $67.12^{\mathrm{a}}$ & 1.08 & $* *$ \\
\hline \multicolumn{7}{|c|}{ Chemical compositionof carcass $\%$} \\
\hline Moisture & 71.174 & 71.684 & 72.084 & 73.03 & 0.19 & NS \\
\hline $\mathrm{DM}$ & 28.826 & 28.316 & 27.916 & 26.97 & 0.17 & NS \\
\hline $\mathrm{CP}$ & 22.194 & 23.264 & 23.008 & 22.56 & 0.21 & NS \\
\hline $\mathrm{EE}$ & $4.072^{\mathrm{a}}$ & $3.162^{\mathrm{b}}$ & $2.066^{\mathrm{c}}$ & $2.026^{\mathrm{c}}$ & 0.14 & $*$ \\
\hline Ash & $1.896^{\mathrm{a}}$ & $1.372^{\mathrm{b}}$ & $1.47^{\mathrm{b}}$ & $1.392^{\mathrm{b}}$ & 0.017 & $*$ \\
\hline
\end{tabular}

$* a, b$, $c$ and $d$ : Means in the same row having different superscripts differ significantly $(P<0.05)$.

NS not significance

\section{Blood plasma biochemical values:}

Effects of dietary treatments on blood plasma biochemical concentration are shown in Table 6. Data for the plasma total protein and HDL showed that there were no significant differences between the experimental groups fed diets containing 25, 50 and $75 \%$ ASB and the control group. Albumin of the rabbits fed 50 and $75 \%$ ASB diets were significantly $(\mathrm{P}<0.05)$ higher than those fed $25 \%$ ASB and control diets. Plasma globulin, triglycerides, cholesterol, vLDL and total lipids were significantly lowered with ASB inclusion in the rabbit diets compared to the control rabbits.Plasma cholesterol and LDL were significantly lowered upon feeding 50 or $75 \%$ ASB compared to the control or $25 \%$ ASB feeding. Higher dietary ASB treatments decreased blood plasma analysis of cholesterol, LDL, vLDL and total lipids. These results may be due to that the leaves of strawberry contain a wide range of phenolic compound classes. This polyphenolic rich strawberry may provide protectionfrom high carbohydrate/fat mealinduced increases infibrinolytic and inflammatory factors (Ellis et al., 2011).

\section{Blood plasma antioxidant constituents:}

Effects of different levels of ASB on blood plasma antioxidative parameters are presented in Table 6 . The blood plasma lipid peroxide (malondialdehyde (MDA) (nmol/l) levels of rabbits fed diets of 50 and $75 \%$ ASB diets were significantly lower compared with control and 25\% ASB diets. MDA level was observed to move down to the highest levels of ASB (50 and 75\%), respectively. The blood plasma total antioxidant capacity (TAC) was within the range of $0.50-3.09 \mathrm{mmol} / \mathrm{l}$. The blood plasma TAC levels of rabbits fed ASB 
at any inclusion level were significantly higher compared with control rabbits. The blood plasma TAC levels were observed to move up constant with increasing dietary levels of ASB. The reduced levels of lipid peroxides following substitution with ASB may have been associated with increased antioxidant enzyme activity. Confirming to our results,Saponjac et al., (2014) reported that the strawberry pomace contained higher amounts of total flavonoids and anthocyanin's, individual phenolic acids and flavonoids, among them protocatechuic acid, catechin and pelargonidin-3-glucoside (1838.31and 1646.68 per $100 \mathrm{~g}$, respectively). Niki (2008) found that lipid peroxidation represents oxidative decomposition of lipids and is an indicator of oxidative stress status in tissues and cells. Kosseva (2013) reported that phenolic compounds are major contributors to the antioxidant capacity of common fruits and vegetables and their agro wastes.

Table (6). Blood plasma biochemical of growing rabbits fed diets containing ASB.

\begin{tabular}{|c|c|c|c|c|c|c|}
\hline \multirow[b]{2}{*}{ Item } & \multicolumn{4}{|c|}{ Treatments } & \multirow[b]{2}{*}{ SEM } & \multirow[b]{2}{*}{ Sign } \\
\hline & $\begin{array}{c}\text { Control } \\
\text { zero }\end{array}$ & $\begin{array}{c}\mathrm{T}_{1} \\
25 \%\end{array}$ & $\begin{array}{c}\mathrm{T}_{2} \\
50 \%\end{array}$ & $\begin{array}{c}\mathrm{T}_{3} \\
75 \%\end{array}$ & & \\
\hline Total protein, (g/dl) & 5.93 & 5.55 & 6.06 & 6.01 & 0.17 & NS \\
\hline Albumin, $(\mathrm{g} / \mathrm{dl})$ & $3.03^{\mathrm{b}}$ & $3.02^{\mathrm{b}}$ & $3.56^{\mathrm{a}}$ & $3.58^{\mathrm{a}}$ & 0.101 & $*$ \\
\hline Globulin (g/dl) & $2.90^{\mathrm{a}}$ & $2.53^{\mathrm{b}}$ & $2.50^{\mathrm{b}}$ & $2.43^{\mathrm{b}}$ & 0.109 & $*$ \\
\hline Triglycerides, (mg/dl) & $81.50^{\mathrm{a}}$ & $75.74^{\mathrm{b}}$ & $70.90^{\mathrm{b}}$ & $67.84^{\mathrm{b}}$ & 2.066 & $*$ \\
\hline Total cholesterol, (mg/dl) & $127.21^{\mathrm{a}}$ & $123.24^{\mathrm{a}}$ & $118.17^{\mathrm{b}}$ & $117.8^{\mathrm{b}}$ & 2.99 & $* *$ \\
\hline HDL, (mg/dl) & 68.97 & 66.43 & 64.78 & 64.57 & 1.499 & NS \\
\hline $\mathrm{LDL},(\mathrm{mg} / \mathrm{dl})$ & $41.94^{\mathrm{a}}$ & $41.662^{\mathrm{a}}$ & $36.21^{\mathrm{b}}$ & $35.06^{\mathrm{b}}$ & 1.057 & $*$ \\
\hline vLDL, (mg/dl) & $16.3^{\mathrm{a}}$ & $15.15^{\mathrm{b}}$ & $14.18^{\mathrm{b}}$ & $13.57^{\mathrm{b}}$ & 0.957 & $* *$ \\
\hline Total Lipid(mg/l) & $346.19^{\mathrm{a}}$ & $302.69^{b}$ & $256.61^{b}$ & $251.02^{\mathrm{b}}$ & 17.34 & $* *$ \\
\hline \multicolumn{7}{|c|}{ Blood plasma antioxidant constituents } \\
\hline $\mathrm{MDA},(\mathrm{nmol} / \mathrm{l})$ & $5.34^{\mathrm{a}}$ & $5.01^{\mathrm{a}}$ & $1.90^{\mathrm{b}}$ & $1.01^{\mathrm{c}}$ & 0.065 & $*$ \\
\hline $\mathrm{TAC},(\mathrm{mMol} / \mathrm{L})$ & $0.50^{\mathrm{d}}$ & $0.83^{\mathrm{c}}$ & $1.06^{\mathrm{b}}$ & $3.09^{\mathrm{a}}$ & 0.098 & $*$ \\
\hline
\end{tabular}

$* a, b, c$ and $d:$ Means in the same row having different superscripts differ significantly $(P<0.05)$.

NS not significance

\section{Economic Evaluation:}

Final body weight, length of the growing period and feeding cost are generally among the most important factors involved in achievement of maximum efficiency values of meat production. The relative economic efficiency (REE) of the different formulated diets as affected by different treatments is shown in Table 7. It should be pointed that the REE values were calculated according to the prevailing market selling price of $1 \mathrm{~kg} \mathrm{LBW}$.

Table (7). Economic analysis of growing rabbits fed diets containing different levels of ASB.

\begin{tabular}{|c|c|c|c|c|}
\hline Items & Control & $\mathrm{T}_{1}$ & $\mathrm{~T}_{2}$ & $\mathrm{~T}_{3}$ \\
\hline Average total weight gain/ rabbit (kg) & 1.629 & 1.687 & 1.678 & 1.706 \\
\hline Total revenue/ rabbit $(\mathrm{LE})^{(1)}$ & 40.73 & 42.18 & 41.95 & 42.65 \\
\hline Total feed consumed/rabbit $(\mathrm{Kg})$ & 3.810 & 3.842 & 3.861 & 3.755 \\
\hline Price of feeding $/ \mathrm{kg}$ (LE) & 2.30 & 2.20 & 2.10 & 2.00 \\
\hline Total cost of feed/ rabbit (LE) & 8.76 & 8.45 & 8.11 & 7.51 \\
\hline Total fixed cost of/ rabbit (LE) & 6 & 6 & 6 & 6 \\
\hline Total cost/ rabbit (LE) & 14.76 & 14.45 & 14.11 & 13.51 \\
\hline Net revenue/ rabbit $\left(\mathrm{LE}^{(2)}\right)$ & 25.97 & 27.73 & 27.84 & 29.14 \\
\hline Economic efficiency $(\mathrm{EE})^{(3)}$ & 1.76 & 1.92 & 1.97 & 2.16 \\
\hline Relative economic efficiency (REE) & 100 & 109.1 & 111.93 & 122.73 \\
\hline
\end{tabular}

Total price for feeds was calculated according to the price of different ingredients available in ARE.

1- The price was calculated due to the local market the price of one ton of ASB (LE) and price of one Kg live weight was $25 \mathrm{LE}$.

2- Net revenue $=$ total revenue/rabbit- total feed cost

3- Economic efficiency= net revenuel total feed coast

4- Relative economic efficiency of the control, assuming that the relative E1 of the control $(T 1)=100$

Results indicated that ASB improved slightly the net revenue and reduced the cost of producing kilogram BW as compared with control group. Data showed that $75 \%$ ASB to growing rabbit gave the 
best economic efficiency (2.16) followed by 50 and $25 \%$ ASB (1.97 and 1.92), when compared to the control group (1.76), respectively. The results indicated that 25, 50 and 75\% ASB as a partial replacement for berseem hay improved the REE of diets by $109.1,111.93$ and $122.73 \%$, respectively, when compared with the control diet . $\% 100.00)$

The results of this study are in agreement with those of Omer et al. (2011) who found that rabbits received diet complete replacement strawberry by-product at the level $100 \%$ of clover hay recorded the highest value of the total revenue, net revenue, economical efficiency and relative economic efficiency were increased. It can be maintained that ASB could be used in rabbit diets.

\section{CONCLUSION}

The results of the current study suggests that dietary supplementation of ASB at 25,50 and $75 \%$ levels as a replacement of berseem hay had no adverse effect on growth performance, digestibility coefficient, carcass traits, blood plasma analysis and economic efficiency. It can be concluded that ASB can be used as a cheap non-traditional source in rabbit's diets at level of $75 \%$ as a replacement of berssem hay.

\section{REFERENCE}

AOAC (1996). Association of Official Analytical ChemistsAssociation of Official Analytical Chemists $16^{\text {th }}$ Edn., Gaithersburd, MD, USA.

Alonso, A.M.; D.A. Guillen; C.G. Barroso; B. Puertasand A. Garcia (2002). Determination of antioxidant activity of wine byproducts and its correlation with polyphenolic content. J. of Agricultural and Food Chemistry, 50:5832-5836.

Alvarez-Suarez, J.M.; D. Dekanski; S. Ristic;N.V. Radonjic;N.D. Petronigevic;F. Giampieri; P.Astolfi;A.M. Gonzalez-Paramas;C. Santos-Buelga;S. Tulipani;J.L. Quiles; B. Mezzettiand M. Battino (2011). Strawberry polyphenols attenuate ethanol-induced gastric lesions in rats by activation of antioxidant enzymes and attenuation of MDA increase. PLOS One, 6(10): e25878.

Amro, B.; T. Aburjai; and S. Al-Khalil (2002).Antioxidative and radical scavenging effects of olive cake extract. Fitoterapia, 73:456-461.

Blasco A. and J. Ouhayoun (1996): Harmonization of criteria and terminology in rabbit meat research. World Rabbit Sci., 4: 93-99.

Calsamiglia, S.; M.D. Stem and J.L. Frinkins (1995). Effects of protein source on nitrogen metabolism in continuous culture and intestinal digestion in vitro. J. Anim. Sci., 73:1819.

Champ, M.; A.M. Langkilde; F.Brouns;B. Kettlitz and Y.L. Bail-Collet (2003). Advances in dietary fibre characterization. 2. Consumption, chemistry physiology and measurement of resistant starchimplications for health and food labeling. Nutr. Res. Rev., 16(2):143-161.

Cheeke, P.R. (1987). Rabbit Feeding and Nutrition. Academic Press, INC.

Chiu, D.T.Y.; F.H. Stults and A.L. Tappel (1976). Purification and properties of rat lung soluble glutathione peroxidase. BiochimicaetBiophysicaActa, 445:558-566.

Dean R.T.; S. Fu; R. Stocker andM.J. Davies (1997). Biochemistry and pathology of radical-mediated protein oxidation. Biochem J., 324:1-18.

Donohoe, D.R.; N. Garge;X. Zhang;W. Sun;T.M. O'Connell; M.K. Bunger and S.J. Bultman (2011). The microbiome and butyrate regulate energy metabolism and autophagy in the mammalian colon. Cell Metabolism, 13(5):517-526.

Du, X.; M. Song and R. Rouseff (2011). Identification of new strawberry sulfur volatiles and changes during maturation. J. Agric. Food Chem., 59(4):1293-1300.

Duan, J. and Y. Zhao (2009). Antimicrobial efficiency of essential oil and freeze-thaw treatments against Escherichia coli O157:H7 and Salmonella enteric Ser. Enteritidis in strawberry juice. J. Food Sci., 74(3):131-137.

Duncan, D.B. (1955): Multiple range and multiple F test testbiomrtrics, 11:1-42.

Ellis, C.L.; I. Edirisinghe;T. Kappagoda andB. Burton-Freeman (2011). Attenuation ofmeal-induced inflammatory and thrombotic responsesin overweight men and women after 6-week dailystrawberry (Fragaria) intake. A randomized place bocontrolled trial. J. AtherosclerThromb., 18 (4):318-327.

Fekete, S. and T. Gippert (1986). Digestibility and nutritive value of nineteen important feedstuffs for rabbits. J. Appl. Rabbit Res., 9:103-108.

Goto, T.;H. Nagai; K. Egawa; Y.Kim; Kato, A. Taimatsu;T. Saka;S. Ebisu;T. Hohsaka; H.Miyagawa; S. Murakami;N. Takahashi and T. Kawada (2011).Farnesyl pyrophosphate regulates adipocyte functions as an endogenous PPAR agonist.Biochem. J., 438(1):111-119. 


\section{Waly et al.}

Industrial Union of Egypt, (2015). Personal communication.

Ka"hko"nen, M.P.; A.I. Hopiaand M. Heinonen (2001): Berry phenolics and their antioxidant activity. J. of Agric. and Food Chem., 49:4076-4082.

Koponen J.M.; A.M. Happonen; P.H. Mattila, and R. Torronen (2007). Contents of anthocyanins in selected foods consumed in Finland. J. Agric. Food Chem., 55:1612-1619.

Kosseva, M.R. (2013). In Food Industry Wastes - Assessment and Recuperation of Commodities, ed. M. Kosseva and C. Webb, Elsevier, Academic Press, London, 2013, pp. 103-120.

Kümeli, T. (2006).Flavonoidlernasılkoruyor www.milliyet.com.tr/ extra/ venus/ vitamin/ vit001/ axvitamin02.html. Accessed: May 26, 2011.

Mc-Dougall, G.J.; F. Shpiro; P. Dobson; P.Smith; A. Blake and D. Stewart (2005). Different polyphenolic components of soft fruits inhibit alpha-amylase and alpha-glucosidase. J. Agric. Food Chem., 6(53) (7):2760-2766.

McGrath, N.A. and R.T. Raines (2011). Chemo selectivity in chemical biology: acyl transfer reactions with sulfur and selenium. Acc. Chem. Res., 44(9):752-761.

Niki, E. (2008). Lipid peroxidation products as oxidative stress biomarkers. Bio-Factors, 34(2):171-180.

Obun, C.O.; S.M. Yahaya;A.A. Kibon;O.A. Olafadehanand S.D. Alison (2010). Evaluation ofDetariummicrocarpumpulp meal as feed ingredientin rabbits diets. EJEAF Che., 9(2):308-314.

Omer, H.A.A.; F.A.F. Aliand A.M. Ibrahim (2011).Strawberry by-products as a partial replacement of clover hay in rabbit diets. American-Eurasian J. Agric. And Environ. Sci., 11 (6):815-823.

Peschel, W.; F. Sa'nchez-Rabaneda; W. Diekmann; A. Plescher; I. Gartz1; D. Jime'nez; 'R. LamuelaRavento; S. Buxaderas and C. Codina (2006).An industrial approach in the search of natural antioxidants from vegetable and fruit wastes. Food Chemistry, 97:137-150.

Pusztai, A.; G. Grant; T. Duguid;D.S. Brown; W.J.Peumans; E.J. Van-Damme and S. Bardocz (1995): Inhibition of starch digestion by alpha-amylaseinhibitor reduces the efficiency of utilization ofdietary proteins and lipids and retards the growth ofrats. J. Nutr., 125(6):1554-1562.

Puupponen-Pimia, R.; L.Nohynek;S. Hartmann-Schmidlin;M. Kahkonen;M. Heinonen;K. MaattaRiihinenand K.M. Oksman-Caldentey(2005). Berry phenolics selectively inhibit the growth of intestinal pathogens. J. Appl. Microbial, 98: 991-1000.

Rus, E.C.; I.Amaya; J.F.S.Sevilla; M.A. Botella and V. Valpuesta (2011). Regulation of L-ascorbicacid content in strawberry fruits. J. Exp. Bot., 62(12): 4191-4201.

Saponjac, V.T.; A.G. Vilaplana; S. Djilas;D.A. Moreno; J.C.Brunet; J. Vuli'c; S. Staj`ci'cand M. Vin ci'c(2014). Chemical composition and potential bioactivity of strawberry pomace. An international J. to further the chemical sciences, (7): 4727-5483.

SAS (1999): User's guid. Statistics. SAS Inst. Cary N. C. Releigh.

Silva,D.J. andA.A.C. Queiroz(2002).AYnalysisfoods: chemical and biologicalmethods.3. ed.Viçosa, MG: UFV, 235p.

Steven Lukefapor, W.D.; W.D. Hohenboken; P.R.Cheeke; N.M. Pattonand W.H. Kennick (1981). Carcass and meat characteristics of Flemish giant and New Zealand white purebred and terminal cross rabbits. $J$. of Applied Rabbit Res., 4 (3), 66-72.

Vulić, J.J.; V.T. Tumbas; S.M. Savatović; S.M. Đilas; G.S. Ćetkovićand J.M.Ĉ. Brunet (2011). Polyphenolic content and antioxidant activity of the four berry fruit pomace extract. Original scientific paper. APTEFF, 42:271-279.

Wicks, D.;J. Wright;P. Rayment and R. Spiller (2005). Impact of bitter taste on gastric motility. Eur. J. GastroenterolHepatol., 17(9):961-965.

Wijngaard, H.; C. Roessle and N. Brunton (2009). A survey of Irish fruit and vegetable waste and byproducts as a source of polyphenolic antioxidants. Food Chemistry, 116:202-207.

Yoshikawa, H.; M. Kotaru; C.Tanaka; T. Ikeuchi and M. Kawabata (1999). Characterization of kintoki bean (Phaseolus vulgaris) alpha-amylase inhibitor: inhibitory activities against human salivary and porcine pancreatic alpha-amylases and activitychanges by proteolytic digestion. J. Nutr. Sci. Vitaminol (Tokyo), 45(6):797-802. 
أمانى حسين والى، محمد بسيونى، عفاف حسن زيدان و حسن محمد فؤاد جلال

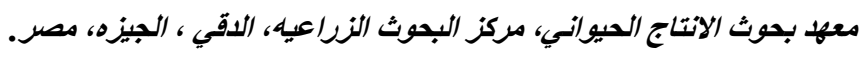

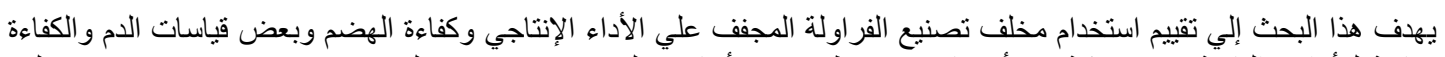

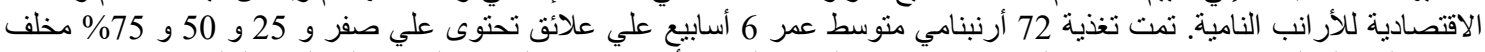

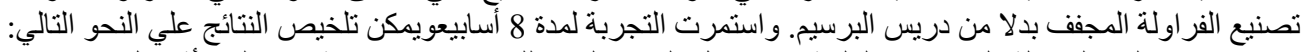

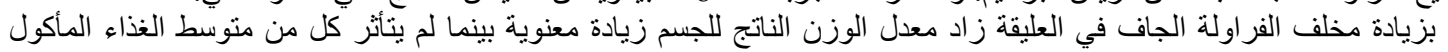

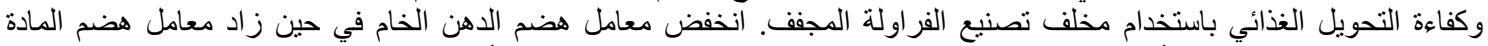

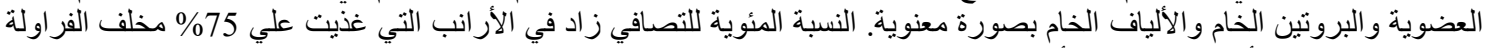

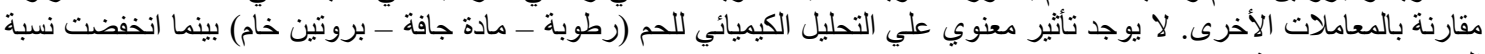

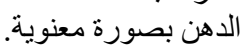

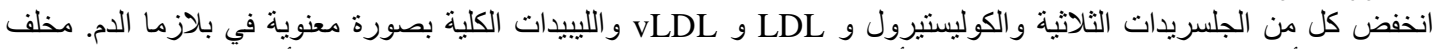

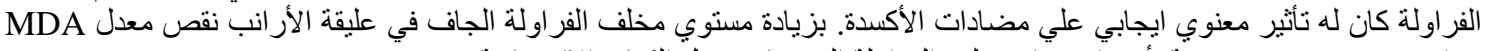

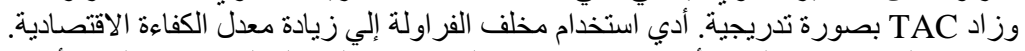

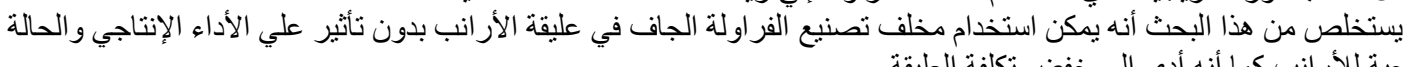

الصحية للأر انب كما أنه أدى إلي خفض نكلف الثفة العليقة. 